Article

\title{
Quality Profile of Single-Breed Alpine Grey and Pinzgauer Bulk Milk
}

\author{
Thomas Zanon ${ }^{1, *}$, Angela Costa ${ }^{2}\left(\mathbb{D}\right.$, Massimo De Marchi ${ }^{2}$, Mauro Penasa ${ }^{2}\left(\mathbb{0}\right.$, Sven König $^{3}$ \\ and Matthias Gauly ${ }^{1}$ \\ 1 Faculty of Science and Technology, Free University of Bolzano, Piazza Università 5, 39100 Bolzano, Italy; \\ matthias.gauly@unibz.it \\ 2 Department of Agronomy, Food, Natural Resources, Animals and Environment, University of Padova, \\ Viale dell'Università 16, 35020 Legnaro, Italy; angela.costa@unipd.it (A.C.); \\ massimo.demarchi@unipd.it (M.D.M.); mauro.penasa@unipd.it (M.P.) \\ 3 Institute of Animal Breeding and Genetics, Justus-Liebig University Giessen, Ludwigstr. 21b, 35390 Giessen, \\ Germany; sven.koenig@agrar.uni-giessen.de \\ * Correspondence: thomas.zanon@unibz.it
}

Received: 17 June 2020; Accepted: 5 July 2020; Published: 10 July 2020

\begin{abstract}
The aim of the present study was to investigate sources of variation in bulk milk composition, somatic cell score, coagulation properties, and mineral content of Alpine Grey and Pinzgauer single-breed herds in the Italian alpine area. A total of 56,914 bulk milk samples from 461 farms located in the Bolzano province (Northeast Italy) were available for statistical analysis. Least squares means revealed that Pinzgauer herds produced milk with greater fat content and shorter rennet coagulation time than Alpine Grey herds, but the latter had greater milk protein content and lower somatic cell scores than Pinzgauer herds. The greatest content of $\mathrm{Ca}$, protein, and casein and the most favorable coagulation properties were observed in milk sampled in autumn in both breeds. Results should serve to differentiate the milk of Alpine Grey cattle and Pinzgauer cattle from milk of other cattle breeds and thus provide necessary arguments for developing new production concepts that might expand future opportunities for further valorizing these local, dual-purpose breeds and therefore contribute long-term to their preservation.
\end{abstract}

Keywords: milk coagulation; mineral; somatic cell score; local breed; Pinzgauer; Alpine Grey

\section{Introduction}

Dairy farming in the alpine area is characterized by small, family-run units often facing mechanical and structural limits [1], resulting in higher production costs compared to lowland farms [2]. Moreover, summer pasturing (transhumance) is a relevant production factor because of the additional forage sources required and the higher revenues for milk transformation into high-value dairy products like cheese [3,4]. Further, the cultivation of mountain pastures using livestock is crucial for preserving marginal areas and land fragmentation and thus preventing succession and simplification of the landscape [5]. Therefore, local cattle breeds are commonly used because of their robustness and adaptability to the alpine environment [6]. Despite this, nowadays the intensification of dairy production on alpine farms is also visible, especially in herds located at lower elevations, where there are less fragmented fields and gentler slopes [2,7]. Hence, alpine farmers have progressively started to move to intensive farming systems with specialized cattle breeds like the Holstein Friesian and Brown Swiss [7]. This has been unfavorable for local dual-purpose breeds of the Alpine region like the Pinzgauer (PI) and Alpine Grey (AG), both known for their feed efficiency, resilience, hard claws, and strong legs [8]. Several authors have demonstrated local cattle breeds to be competitive 
with cosmopolitan dairy breeds in terms of milk composition and coagulation ability [6,9]; this may enable alpine farmers to valorize milk produced by local breeds through niche and branded cheese products by which they can partially compensate for the higher production costs and lower milk production compared to intensive farming $[6,10]$. In fact, PI and AG farmers can only play on a few aspects to maximize their profit; for instance, they should be involved in projects intended to valorize milk and dairy product quality. Therefore, information about technological traits and bulk milk quality in regard to PI and AG herds is essential for both farmers and the local dairy industry, although no prior studies considering such aspects on a large data scale were found. Thus, the objectives of this study were to investigate the effect of season on bulk milk quality traits, including milk coagulation properties (MCPs) and mineral content, and to compare the milk of AG and PI single-breed herds to provide research results relevant to milk processing practices in the mountain area.

\section{Materials and Methods}

\subsection{Area of Study}

The Province of Bolzano is located in the northern part of Italy and is characterized by mountainous topography and small-scale, family-run farms. Approximately 8000 South Tyrolean farms are engaged in animal husbandry, using 71,862 hectares of grass, pastural, and arable land to produce forage [11]. In total, 128,000 cattle are kept in South Tyrol, of which $52 \%$ are dairy cows (approximately $13 \%$ and $2 \%$ out of them are AG and PI cows, respectively) producing approximately 400,000 tons of milk per year [12].

\subsection{Bulk Milk Data}

Information on bulk milk samples of AG and PI single-breed herds, collected between January 2014 and December 2018, was retrieved from the databases of the South Tyrolean Dairy Association and the Breeders Association of Bolzano Province (Bolzano, Italy). The original data comprised 66,712 records of 463 farms, with information on fat content (FC), protein content (PC), casein content (CC), lactose content (LC), and somatic cell count (SCC; cells $/ \mathrm{mL}$ ). Mid-infrared spectroscopy analyses were performed in the laboratory of the South Tyrolean Dairy Association using Milkoscan FT6000 (Foss, Hillerød, Denmark) and, from March 2017, Milkoscan FT7 (Foss, Hillerød, Denmark). In the same laboratory, SCC was determined by Fossomatic FC (Foss, Hillerød, Denmark). Milk MCPs and mineral content $(\mathrm{mg} / \mathrm{kg}$ ) were predicted a posteriori using the prediction models developed by Visentin et al. [13] on the stored milk spectra. Briefly, individual milk samples $(n=923)$ of Holstein Friesian, Brown Swiss, and AG cattle were used to analyze minerals and MCPs with both Formagraph (Foss Electric A/S) and mid-infrared spectroscopy. Prediction models were calibrated by applying partial least squares regression and uninformative variable elimination [13]. Coefficients of determination were $70 \%$ for $\mathrm{Mg}, \mathrm{Ca}, \mathrm{K}$, and $\mathrm{P} ; 40 \%$ for $\mathrm{Na} ; 54 \%$ for rennet coagulation time (RCT); and $56 \%$ for curd-firming time $\left(k_{20}\right)$ [13]. In the following study, MCPs included rennet coagulation time (RCT, min), curd-firming time $\left(\mathrm{k}_{20}, \mathrm{~min}\right)$, and curd firmness $30 \mathrm{~min}$ after rennet addition to milk $\left(\mathrm{a}_{30}, \mathrm{~mm}\right)$, and the milk minerals were $\mathrm{Ca}, \mathrm{K}, \mathrm{Mg}, \mathrm{Na}$, and $\mathrm{P}$. The coefficients of determination of the prediction models in external validation were $0.67,0.69,0.65,0.40,0.68,0.54,0.56$, and 0.52 for $\mathrm{Ca}, \mathrm{K}, \mathrm{Mg}, \mathrm{Na}, \mathrm{P}, \mathrm{RCT}, \mathrm{k}_{20}$, and $\mathrm{a}_{30}$, respectively. Values of milk composition traits, MCPs, and minerals outside mean \pm 3 standard deviations were considered outliers and treated as missing data. SCC values were treated as missing information when they were outside the range of 1 to 1000 cells $/ \mathrm{mL}$. To normalize SCC, the somatic cell score (SCS; units) was conventionally calculated as

$$
\mathrm{SCS}=\log 2(\mathrm{SCC} / 100)+3
$$

Only single-breed farms (i.e., farms with $100 \%$ of cows tested in a year belonging either to breed AG or PI) were included. In fact, farms keeping other breeds next to PI or AG or keeping both AG and PI in multibreed herds were discarded due to very few observations available. Finally, farms that were sampled from a minimum of 3 to a maximum of 10 times in a month and that had at least three 
controlled cows per year were retained, resulting, on average, in nine controlled cows per farm per year. The final dataset comprised 56,914 bulk milk samples of 461 herds: $85.55 \%$ of samples belonged to 405 AG farms, and the remaining $14.45 \%$ belonged to 56 PI farms.

\subsection{Statistical Analysis}

An analysis of variance was performed using SAS software v. 9.4 (SAS Institute Inc., Cary, NC, USA) according to the following linear mixed model:

$$
y_{\mathrm{ijklm}}=\mu+\text { breed }_{\mathrm{i}}+\text { season }_{\mathrm{j}}+\text { year }_{\mathrm{k}}+\left(\text { breed }_{\mathrm{season}}\right)_{\mathrm{ij}}+\left(\text { breed } \times \text { year }_{\mathrm{ik}}+\text { herd }_{1}\left(\text { breed }_{\mathrm{i}}\right)+e_{\mathrm{ijklm}}\right.
$$

where $y_{\mathrm{ijk} k m}$ is FC, PC, CC, LC, SCS, minerals $\left(\mathrm{Ca}, \mathrm{K}, \mathrm{Mg}\right.$, Na, or P), or MCPs $\left(\mathrm{a}_{30}, \mathrm{k}_{20}\right.$, or RCT); $\mu$ is the overall intercept of the model; breed $_{i}$ is the fixed effect of the ith cattle breed $(i=\mathrm{AG}, \mathrm{PI})$; season $_{\mathrm{j}}$ is the fixed effect of the jth season of sampling ( $j$ = winter (December to February), spring (March to May), summer (June to August), autumn (September to November)); year ${ }_{\mathrm{k}}$ is the fixed effect of the kth year of sampling $(k=2014 \text { to 2018); (breed } \times \text { season) })_{\mathrm{ij}}$ is the fixed interaction effect between breed and season of sampling; (breed $\times$ year) ik $_{\text {ik }}$ is the fixed interaction effect between breed and year of sampling; herd ${ }_{1}\left(\right.$ breed $\left._{\mathrm{i}}\right)$ is the random effect of the lth herd nested within the ith breed; and $e_{\mathrm{ijklm}}$ is the random residual term. According to the data structure, the significance of the breed effect was tested on the herd within breed variance. Post hoc Bonferroni adjustment was used to test if least squares means differed significantly $(p<0.05)$.

\section{Results}

\subsection{Descriptive Statistics and Correlations}

Milk FC, PC, CC, and LC averaged 3.80\%, 3.43\%, 2.68\%, and $4.82 \%$, respectively (Table 1) and SCS ranged from -3.64 to 6.32 . The coefficient of variation (CV) of traditional milk quality traits varied from $1.50 \%$ (LC) to $32.17 \%$ (SCS). Rennet coagulation time, $\mathrm{k}_{20}$, and $\mathrm{a}_{30}$ averaged $22.75 \mathrm{~min}$, $7.29 \mathrm{~min}$, and $16.02 \mathrm{~mm}$, respectively (Table 1) and mineral content ranged from $136.28 \mathrm{mg} / \mathrm{kg}(\mathrm{Mg}$ ) to $1570.72 \mathrm{mg} / \mathrm{kg}(\mathrm{K})$ and showed low CVs $(<10 \%$; Table 1$)$.

Table 1. Descriptive statistics of bulk milk traits.

\begin{tabular}{|c|c|c|c|c|c|}
\hline Trait & $N$ & Mean & $\mathrm{CV}, \%$ & Minimum & Maximum \\
\hline \multicolumn{6}{|c|}{ Milk Composition (\%) } \\
\hline Fat & 56,541 & 3.80 & 6.17 & 3.09 & 4.52 \\
\hline Protein & 56,682 & 3.43 & 5.09 & 2.90 & 3.95 \\
\hline Casein & 56,650 & 2.68 & 5.12 & 2.27 & 3.08 \\
\hline Lactose & 56,511 & 4.82 & 1.50 & 4.60 & 5.03 \\
\hline SCS, units & 56,435 & 3.17 & 32.17 & -3.64 & 6.32 \\
\hline \multicolumn{6}{|c|}{ Milk Coagulation Properties } \\
\hline $\mathrm{a}_{30}, \mathrm{~mm}$ & 56,098 & 16.02 & 41.19 & 0.00 & 36.16 \\
\hline $\mathrm{k}_{20}, \min$ & 56,517 & 7.29 & 9.35 & 5.16 & 9.39 \\
\hline $\mathrm{RCT}, \mathrm{min}$ & 56,563 & 22.75 & 10.99 & 15.02 & 30.51 \\
\hline \multicolumn{6}{|c|}{ Mineral Content, $\mathrm{mg} / \mathrm{kg}$} \\
\hline $\mathrm{Ca}$ & 56,583 & 1328.09 & 4.35 & 1152.27 & 1507.40 \\
\hline $\mathrm{K}$ & 56,426 & 1570.72 & 4.48 & 1348.92 & 1794.16 \\
\hline $\mathrm{Mg}$ & 56,583 & 136.28 & 7.86 & 103.21 & 169.21 \\
\hline $\mathrm{Na}$ & 56,417 & 398.42 & 8.84 & 287.05 & 509.86 \\
\hline $\mathrm{P}$ & 56,823 & 1075.66 & 9.50 & 771.98 & 1382.99 \\
\hline
\end{tabular}

SCS: somatic cell score; $\mathrm{a}_{30}$ : curd firmness $30 \mathrm{~min}$ after rennet addition to milk; $\mathrm{k}_{20}$ : curd-firming time; RCT: rennet coagulation time; $n$ : number of observations; $\mathrm{CV}$ : coefficient of variation. 
Pearson correlations $(p<0.05)$ between the investigated traits are summarized in Table 2. The strongest relationships $(p<0.05)$ were estimated between PC and CC $(0.98), \mathrm{a}_{30}$ and RCT $(-0.90)$, and $\mathrm{Mg}$ and $\mathrm{P}(0.73)$. Milk SCS was very weakly correlated with all traits except LC $(-0.30 ; p<0.05)$ and $\mathrm{Na}(0.26 ; p<0.05)$. The greater content of $\mathrm{Na}$ and $\mathrm{K}$ in milk translated into worse MCPs $(p<0.05)$, i.e., longer RCT and less firm curd (Table 2).

Table 2. Pearson correlations $(p<0.05)$ between bulk milk composition traits, coagulation properties, and mineral content $(\mathrm{mg} / \mathrm{kg})$.

\begin{tabular}{|c|c|c|c|c|c|c|c|c|c|c|c|c|}
\hline Trait & FC & PC & $\mathrm{CC}$ & LC & SCS & $\mathbf{a}_{30}$ & $k_{20}$ & $\mathrm{RCT}$ & Ca & $\mathbf{K}$ & Mg & $\mathrm{Na}$ \\
\hline $\mathrm{PC}$ & 0.37 & & & & & & & & & & & \\
\hline $\mathrm{CC}$ & 0.40 & 0.98 & & & & & & & & & & \\
\hline LC & -0.06 & -0.10 & -0.03 & & & & & & & & & \\
\hline SCS & 0.08 & 0.11 & 0.09 & -0.30 & & & & & & & & \\
\hline$a_{30}$ & 0.09 & 0.18 & 0.13 & 0.05 & -0.04 & & & & & & & \\
\hline $\mathrm{k}_{20}$ & -0.23 & -0.51 & -0.50 & -0.04 & $\begin{array}{c}-0.01 \\
\mathrm{~ns}\end{array}$ & -0.61 & & & & & & \\
\hline $\mathrm{RCT}$ & -0.02 & $\begin{array}{c}0.00 \\
\text { ns }\end{array}$ & 0.02 & -0.06 & 0.07 & -0.90 & 0.55 & & & & & \\
\hline $\mathrm{Ca}$ & 0.27 & 0.47 & 0.40 & -0.05 & 0.15 & 0.26 & -0.39 & -0.13 & & & & \\
\hline K & -0.22 & 0.07 & 0.09 & -0.10 & $\begin{array}{c}-0.01 \\
\mathrm{~ns}\end{array}$ & -0.27 & -0.11 & 0.21 & -0.22 & & & \\
\hline $\mathrm{Mg}$ & 0.19 & 0.28 & 0.26 & -0.12 & 0.08 & 0.11 & -0.48 & -0.09 & 0.49 & 0.40 & & \\
\hline $\mathrm{Na}$ & 0.02 & 0.08 & 0.07 & -0.60 & 0.26 & -0.28 & -0.08 & 0.25 & -0.02 & 0.48 & 0.40 & \\
\hline $\mathrm{P}$ & 0.09 & 0.39 & 0.32 & 0.06 & $\begin{array}{c}-0.02 \\
\text { ns }\end{array}$ & 0.27 & -0.47 & -0.20 & 0.57 & 0.18 & 0.73 & -0.14 \\
\hline
\end{tabular}

FC: fat content (\%); PC: protein content (\%); CC: casein content (\%); LC: lactose content (\%); SCS: somatic cell score (units); $\mathrm{a}_{30}$ : curd firmness $30 \mathrm{~min}$ after rennet addition to milk (mm); $\mathrm{k}_{20}$ : curd-firming time (min); RCT: rennet coagulation time (min); ns: not significant.

\subsection{Analysis of Variance}

Results of the analysis of variance are summarized in Table 3. Overall, fixed effects introduced in the statistical model significantly explained the variation in the investigated traits $(p<0.05)$, except for the effect of breed (for CC, LC, $\mathrm{a}_{30}, \mathrm{k}_{20}, \mathrm{Ca}$, and $\mathrm{Na}$ ) and for the fixed interaction between breed and season (for $\mathrm{k}_{20}$ and $\mathrm{Ca}$ ).

Table 3. F-value and significance of fixed effects included in the analysis of variance for bulk milk traits.

\begin{tabular}{|c|c|c|c|c|c|c|}
\hline Trait & Breed & Season & Year & Breed $\times$ Season & Breed $\times$ Year & RSD \\
\hline \multicolumn{7}{|c|}{ Milk composition (\%) } \\
\hline Fat & $81.52 * * *$ & $275.56^{* * *}$ & $50.74^{* * *}$ & $30.95^{* * *}$ & $4.07^{* *}$ & 0.18 \\
\hline Protein & $4.82 *$ & $547.04^{* * *}$ & $53.95^{* * *}$ & $61.39^{* * *}$ & $10.64^{* * *}$ & 0.13 \\
\hline Casein & $1.84^{\mathrm{ns}}$ & $436.10^{* * *}$ & $216.26^{* * *}$ & $56.18^{* * *}$ & $13.90^{* * *}$ & 0.10 \\
\hline Lactose & $2.07^{\mathrm{ns}}$ & $1005.15^{* * *}$ & $61.20 * * *$ & $20.93^{* * *}$ & $21.35^{* * *}$ & 0.05 \\
\hline SCS (units) & $15.89^{* * *}$ & $139.22 * * *$ & $37.17^{* * *}$ & $9.95^{* * *}$ & $37.46^{* * *}$ & 0.60 \\
\hline \multicolumn{7}{|l|}{ MCPs } \\
\hline $\mathrm{a}_{30}(\mathrm{~mm})$ & $2.96^{\mathrm{ns}}$ & $346.16^{* * *}$ & $2143.16^{* * *}$ & $28.21^{* * *}$ & $13.90^{* * *}$ & 5.14 \\
\hline $\mathrm{k}_{20}(\mathrm{~min})$ & $0.97^{\mathrm{ns}}$ & $467.90^{* * *}$ & $870.26^{* * *}$ & $1.99 \mathrm{~ns}$ & $91.82^{* * *}$ & 0.55 \\
\hline RCT (min) & $11.20^{* * *}$ & $279.67^{* * *}$ & $1358.40^{* * *}$ & $38.00 * * *$ & $17.07^{* * *}$ & 2.06 \\
\hline \multicolumn{7}{|c|}{ Minerals $(\mathrm{mg} / \mathrm{kg})$} \\
\hline $\mathrm{Ca}$ & $0.13^{\mathrm{ns}}$ & $414.80^{* * *}$ & $1500.54^{* * *}$ & $2.42^{\mathrm{ns}}$ & $10.90^{* * *}$ & 45.61 \\
\hline K & $38.44^{* * *}$ & $257.78^{* * *}$ & $1069.77^{* * *}$ & $19.66^{* * *}$ & $5.70^{* * *}$ & 60.93 \\
\hline $\mathrm{Mg}$ & $23.10^{* * *}$ & $685.01^{* * *}$ & $3094.51^{* * *}$ & $11.02^{* * *}$ & $3.28^{* *}$ & 7.93 \\
\hline $\mathrm{Na}$ & $0.42^{\mathrm{ns}}$ & $719.04^{* * *}$ & $530.41^{* * *}$ & $6.70^{* * *}$ & $17.74^{* * *}$ & 29.08 \\
\hline $\mathrm{P}$ & $12.09 * * *$ & $1126.77^{* * *}$ & $4644.98^{* * *}$ & $5.26^{* *}$ & $7.22 * * *$ & 66.75 \\
\hline
\end{tabular}

SCS: somatic cell score; MCPs: milk coagulation properties; $\mathrm{a}_{30}$ : curd firmness $30 \mathrm{~min}$ after rennet addition to milk; $k_{20}$ : curd-firming time; RCT: rennet coagulation time; RSD: residual standard deviation; ns: not significant; ${ }^{*} p<0.05,{ }^{* *} p<0.01,{ }^{* * *} p<0.001$. 
FC was lower in the milk of AG herds than in the milk of PI herds $(p<0.05$; Table 4$)$. On the contrary, AG milk was characterized by greater PC than PI milk $(p<0.05)$. Further, more favorable SCSs were observed in AG than in PI herds $(p<0.05$; Table 4). On the other hand, small differences were observed between AG and PI for MCPs and milk minerals (Table 4).

Table 4. Least squares means of bulk milk traits for the fixed effect of breed.

\begin{tabular}{|c|c|c|c|c|}
\hline \multirow{2}{*}{ Trait } & \multicolumn{2}{|c|}{ Alpine Grey } & \multicolumn{2}{|c|}{ Pinzgauer } \\
\hline & LSM & SE & LSM & SE \\
\hline \multicolumn{5}{|l|}{ Milk composition (\%) } \\
\hline Fat & $3.78^{b}$ & 0.01 & $3.95^{\mathrm{a}}$ & 0.02 \\
\hline Protein & $3.41^{\mathrm{a}}$ & 0.01 & $3.37^{b}$ & 0.02 \\
\hline Casein & 2.66 & 0.00 & 2.65 & 0.01 \\
\hline Lactose & 4.82 & 0.00 & 4.81 & 0.01 \\
\hline SCS, units & $3.03^{b}$ & 0.04 & $3.43^{\mathrm{a}}$ & 0.09 \\
\hline \multicolumn{5}{|l|}{ MCPs } \\
\hline $\mathrm{a}_{30}, \mathrm{~mm}$ & 15.19 & 0.13 & 15.84 & 0.35 \\
\hline $\mathrm{k}_{20}, \min$ & 7.35 & 0.02 & 7.40 & 0.05 \\
\hline $\mathrm{RCT}, \mathrm{min}$ & $22.89^{a}$ & 0.05 & $22.41^{b}$ & 0.13 \\
\hline \multicolumn{5}{|l|}{ Minerals (mg/kg) } \\
\hline $\mathrm{Ca}$ & 1319.75 & 1.39 & 1321.18 & 3.68 \\
\hline $\mathrm{K}$ & $1576.40^{\mathrm{a}}$ & 1.10 & $1557.14^{\mathrm{b}}$ & 2.90 \\
\hline $\mathrm{Mg}$ & $135.35^{b}$ & 0.16 & $137.59^{\mathrm{a}}$ & 0.44 \\
\hline $\mathrm{Na}$ & 399.64 & 0.92 & 401.32 & 2.44 \\
\hline $\mathrm{P}$ & $1066.33^{\mathrm{a}}$ & 2.16 & $1044.97^{\mathrm{b}}$ & 5.75 \\
\hline
\end{tabular}

$\mathrm{a}_{30}$ : curd firmness $30 \mathrm{~min}$ after rennet addition to milk; $\mathrm{k}_{20}$ : curd-firming time; RCT: rennet coagulation time; MCPs: milk coagulation properties; SCS: somatic cell score; different superscript letters within a row indicate statistical significance $(p<0.05)$.

Least squares means of the interactions between breed and season effects are reported in Table 5 . Milk FC was greater in PI than in AG herds $(p<0.05)$ throughout the year and was at its maximum in autumn and winter for PI and in spring and winter for AG. Significant differences in PC between the two breeds were detected in spring and summer, with AG exhibiting greater PC compared to PI. Overall, PC and CC were at their maximum in autumn and at their minimum in summer for both breeds, whereas LC was at its greatest in spring and at its lowest in autumn $(p<0.05$; Table 5$)$. Milk SCS was greater in PI than in AG herds across seasons $(p<0.05)$, and it was at its maximum in summer and autumn and at its minimum in winter and spring, whereas RCT and $\mathrm{a}_{30}$, while not significantly different for all seasons, tended to be more favorable in PI than in AG milk across the year. In fact, the most unfavorable $\mathrm{a}_{30}$ and RCT were observed in AG milk sampled in summer (Table 5). In both breeds, when milk PC, CC, Ca, P, and Mg were the greatest (autumn), good coagulation performances $\left(\mathrm{a}_{30}\right.$ and $\left.\mathrm{RCT}\right)$ were observed. 
Table 5. Least squares means of bulk milk traits for the interactions between breed and seasons of sampling.

\begin{tabular}{|c|c|c|c|c|c|c|c|c|}
\hline \multirow[t]{2}{*}{ Trait } & \multicolumn{2}{|c|}{$\begin{array}{c}\text { Winter } \\
\text { (December to February) }\end{array}$} & \multicolumn{2}{|c|}{$\begin{array}{c}\text { Spring } \\
\text { (March to May) }\end{array}$} & \multicolumn{2}{|c|}{$\begin{array}{c}\text { Summer } \\
\text { (June to August) }\end{array}$} & \multicolumn{2}{|c|}{$\begin{array}{c}\text { Autumn } \\
\text { (September to November) }\end{array}$} \\
\hline & Alpine Grey & Pinzgauer & Alpine Grey & Pinzgauer & Alpine Grey & Pinzgauer & Alpine Grey & Pinzgauer \\
\hline \multicolumn{9}{|c|}{ Milk composition (\%) } \\
\hline Fat & $3.81^{\mathrm{d}}$ & $3.99^{\mathrm{a}}$ & $3.79^{e}$ & $3.95^{b}$ & $3.74^{\mathrm{g}}$ & $3.89^{c}$ & $3.77^{\mathrm{f}}$ & $3.98^{\mathrm{a}}$ \\
\hline Protein & $3.42^{\mathrm{cf}}$ & $3.40^{\mathrm{bfgh}}$ & $3.41^{\mathrm{dg}}$ & $3.35^{\mathrm{i}}$ & $3.38^{\text {ehi }}$ & $3.32^{j}$ & $3.44^{\mathrm{ab}}$ & 3.42 acde \\
\hline Casein & $2.67^{\mathrm{dfg}}$ & $2.66^{\mathrm{bfh}}$ & $2.67^{\mathrm{dfg}}$ & $2.64^{\mathrm{cgi}}$ & 2.64 ehij & $2.60^{\mathrm{j}}$ & $2.68^{a b c}$ & 2.68 ade \\
\hline Lactose & 4.82 ef & $4.80^{\mathrm{dfh}}$ & $4.84^{\mathrm{a}}$ & $4.84^{\mathrm{ab}}$ & $4.82 \mathrm{bcd}$ & $4.81^{\mathrm{ceg}}$ & 4.80 ghi & $4.78^{i}$ \\
\hline SCS, units & $2.91^{\mathrm{e}}$ & $3.33^{b c}$ & $3.00^{\mathrm{d}}$ & $3.33^{b c}$ & $3.17^{\mathrm{b}}$ & $3.55^{\mathrm{a}}$ & $3.04^{c}$ & $3.52^{\mathrm{a}}$ \\
\hline \multicolumn{9}{|l|}{ MCPs } \\
\hline $\mathrm{a}_{30}, \mathrm{~mm}$ & $15.53^{\mathrm{cd}}$ & $16.64^{\mathrm{ac}}$ & $14.74^{\mathrm{e}}$ & $16.00^{b d}$ & $13.74^{\mathrm{f}}$ & 14.20 ef & $16.72^{a b}$ & $16.51^{\mathrm{abc}}$ \\
\hline $\mathrm{k}_{20}, \min$ & 7.34 fhi & $7.37 \mathrm{dgh}$ & $7.43^{\text {beg }}$ & $7.46^{\text {cef }}$ & 7.48 acd & $7.54 \mathrm{ab}$ & $7.15^{\mathrm{j}}$ & $7.21 \mathrm{ij}$ \\
\hline $\mathrm{RCT}$, min & $22.93^{c}$ & $22.31^{\mathrm{d}}$ & $23.14^{b}$ & $22.39^{\mathrm{d}}$ & $23.35^{\mathrm{a}}$ & $22.85^{b c}$ & 22.12 de & $22.09^{e}$ \\
\hline \multicolumn{9}{|c|}{ Minerals $(\mathrm{mg} / \mathrm{kg}$ ) } \\
\hline $\mathrm{Ca}$ & 1319.71 cef & $1323.10^{\mathrm{bcd}}$ & $1307.89 \mathrm{hj}$ & $1307.76^{\text {fij }}$ & $1315.91 \mathrm{dgi}$ & $1318.22 \mathrm{egh}$ & $1335.47^{\mathrm{ab}}$ & $1335.64^{\mathrm{a}}$ \\
\hline K & 1561.62 def & $1540.48^{g}$ & $1579.60^{b}$ & $1569.79 \mathrm{bcd}$ & $1575.18^{c}$ & $1555.08^{f}$ & $1589.20^{\mathrm{a}}$ & $1563.21^{\mathrm{e}}$ \\
\hline $\mathrm{Mg}$ & $134.49^{\mathrm{d}}$ & $136.06^{c}$ & $133.48^{f}$ & $136.53^{c}$ & $134.14^{\mathrm{e}}$ & $136.55^{c}$ & $139.29^{b}$ & $141.22^{\mathrm{a}}$ \\
\hline $\mathrm{Na}$ & $390.38 \mathrm{df}$ & 390.42 ef & $393.95^{\text {ce }}$ & $395.56^{\mathrm{cd}}$ & $406.74^{\mathrm{ab}}$ & $407.61^{b}$ & $407.48^{\mathrm{ab}}$ & $411.69^{a}$ \\
\hline $\mathrm{P}$ & $1081.67^{b}$ & $1058.68^{d}$ & $1054.2^{\text {cde }}$ & 1038.59 ef & $1034.26^{f}$ & $1011.26^{g}$ & $1095.17^{\mathrm{a}}$ & $1071.36^{b c}$ \\
\hline
\end{tabular}

SCS: somatic cell score; MCPs: milk coagulation properties; $\mathrm{a}_{30}$ : curd firmness $30 \mathrm{~min}$ after rennet addition to milk; $\mathrm{k}_{20}$ : curd-firming time; RCT: rennet coagulation time; different superscript letters within row indicate statistical significance $(p<0.05)$.

\section{Discussion}

Descriptive statistics resembled findings of Benedet et al. [14]; in fact, authors reported means of $3.86 \%, 3.34 \%$, and $2.58 \%$ for FC, PC, and CC, respectively, in bulk milk samples of 627 herds located in 11 Italian regions and predominantly composed of Holstein Friesian, Brown Swiss, and Simmental breeds. Considering SCS, the mean and the CV differed than those observed by Benedet et al. [14]. As regards MCPs, values indicate more favorable coagulation characteristics of AG and PI bulk milk compared to MCPs obtained by Benedet et al. [14]. In contrast, Toffanin et al. [15] observed more favorable MCPs measured from 1570 bulk milk samples of 436 Holstein Friesian herds compared to our study. Moreover, Manuelian et al. [16] reported similar RCT and $\mathrm{a}_{30}$ (22.66 min and $16.79 \mathrm{~mm}$, respectively) and lower $\mathrm{k}_{20}(5.53 \mathrm{~min})$ in individual milk samples of 1558 Pinzgauer cows compared to our results (Table 1 ).

Niero et al. [17] observed mean milk mineral content ranging between $110.07 \mathrm{mg} / \mathrm{kg}(\mathrm{Mg})$ and $1493.53 \mathrm{mg} / \mathrm{kg}(\mathrm{K})$ with the $\mathrm{CV}$ varying between $11.36 \%(\mathrm{~K})$ and $39.75 \%(\mathrm{Na})$ in individual milk samples from 83 Burlina cows, a local dual-purpose breed present in the North-East of Italy. Likewise, Manuelian et al. [16] reported mean values between $141.41 \mathrm{mg} / \mathrm{kg}(\mathrm{Mg})$ and $1495.04 \mathrm{mg} / \mathrm{kg}(\mathrm{K})$ with a CV varying between $8.61 \%(\mathrm{~K})$ and $17.59 \%(\mathrm{Mg})$ in Pinzgauer cows.

The positive correlations of $\mathrm{Ca}, \mathrm{Mg}$, and $\mathrm{P}$ with PC and CC $(p<0.05)$ were expected since these minerals are involved in the structure of casein micelles and are crucial for casein micelle stability [18,19]. Moreover, the same minerals were favorably associated with MCPs $(p<0.05)$, suggesting that greater $\mathrm{Ca}, \mathrm{Mg}$, and $\mathrm{P}$ were associated with faster coagulation and greater curd firmness. Overall, the associations estimated in the present study were in agreement with those found in the individual milk of Holstein [20,21], Pinzgauer [16], and other cattle breeds [22]. Finally, the correlations between Na, SCS, and LC were in line with findings reported by Costa et al. [20,23] and confirmed these trait as indicators of udder inflammation. In fact, the strong inverse relationship between Na and LC $(-0.60, p<0.05$; Table 2$)$ was expected since Na acts as an osmole when LC is low, i.e. during mastitis [23]. In individual milk, both the genetic and the phenotypical correlations between these two traits were moderate to high and negative $[20,21]$.

To the best of our knowledge, this is the first study comparing bulk milk quality, MCPs, and minerals of AG and PI cows on a large scale. The lower FC and SCS of AG herds was expected since the AG breed is known to produce less milk fat compared to other cattle breeds [24] and with more favorable 
SCS. This is shown also in the annual report of ZuchtData [25] based on Austrian cow data, where PI milk was found to have a higher average SCC than AG milk.

In the present study, the significance of year and season of sampling effects on the studied traits (Table 3) might be attributed to the fluctuations of seasonal climatic conditions within and between years in the alpine area [26]; such fluctuations affect both feed quality and quantity [27] and indirectly affect management practices (e.g., pasture use and transhumance). In general, in both breeds, when milk PC, $\mathrm{CC}, \mathrm{Ca}, \mathrm{P}$, and $\mathrm{Mg}$ were the greatest (autumn), good coagulation performances ( $\mathrm{a}_{30}$ and RCT) were observed. This was in agreement with the findings of De Marchi et al. [6], who observed better RCT and $\mathrm{a}_{30}$ in autumn compared to other seasons.

\section{Conclusions}

This study compared bulk milk quality of single-breed farms of AG and PI, two dual-purpose breeds of the Alpine region. The milk of PI herds was characterized by greater FC and slightly better MCPs than the milk of AG herds. However, SCS was lower in the milk of AG herds. The most favorable $\mathrm{MCPs}$ were observed in milk collected in autumn in both breeds, i.e., when PC, CC, Ca, P, and Mg were at their maximum. Considering that these two breeds have limited diffusion and are nowadays mostly kept on small, single-breed farms, the milk quality investigation provided in this study is helpful to the local dairy industry in differentiating the milk of Alpine Grey cattle and Pinzgauer cattle from milk of other cattle breeds in order to have necessary arguments for developing new production concepts (e.g., producing location-bound cheese specialties) that might increase profitability and competitiveness of these local, dual-purpose breeds, contribute long-term to their preservation, and add value to alpine dairy farming. Nevertheless, special attention should be paid to feeding practices and management factors, since both have a great impact on milk composition and quality. Thus, specific information on farm housing and feeding should be collected on a large scale to allow fair comparisons.

Author Contributions: Data curation, T.Z. and A.C.; formal analysis, M.P.; funding acquisition, M.G.; investigation, T.Z.; methodology, A.C. and M.D.M.; project administration, M.D.M.; supervision, A.C., M.P., S.K., and M.G.; validation, T.Z. and A.C.; visualization, T.Z.; writing-original draft, T.Z.; writing-review \& editing, A.C., M.P., S.K., and M.G. All authors have read and agreed to the published version of the manuscript.

Funding: The present study is part of the project EIFEAL (CUP: I56C18002030002).

Acknowledgments: The authors would like to thank the Breeders Association of Bolzano Province (Bolzano, Italy) and the milk laboratory of the South Tyrolean Dairy Association (Bolzano, Italy) for providing data used in this study.

Conflicts of Interest: The authors report no potential conflict of interest. The funders had no role in the design of the study; in the collection, analyses, or interpretation of data; in the writing of the manuscript; or in the decision to publish the results.

\section{References}

1. MacDonald, D.; Crabtree, J.R.; Wiesinger, G.; Dax, T.; Stamou, N.; Fleury, P.; Gutierrez Lazpita, J.; Gibon, A. Agricultural abandonment in mountain areas of Europe: Environmental consequences and policy response. J. Environ. Manag. 2000, 59, 47-69. [CrossRef]

2. Zendri, F.; Sturaro, E.; Ramanzin, M. Highland summer pastures play a fundamental role for dairy systems in an Italian alpine region. Agric. Conspec. Sci. 2013, 78, 295-299.

3. Koczura, M.; Bouchon, M.; Turille, G.; De Marchi, M.; Kreuzer, M.; Berard, J.; Martin, B. Consequences of walking or transport by truck on milk yield and quality, as well as blood metabolites, in Holstein, Montbéliarde, and Valdostana dairy cows. J. Dairy Sci. 2020, 103, 3470-3478. [CrossRef]

4. Koczura, M.; Martin, B.; Turille, G.; De Marchi, M.; Kreuzer, M.; Berard, J. Milk composition, but not cheese properties, are impaired the day after transhumance to alpine pastures. Int. Dairy J. 2019, 99, 104540. [CrossRef]

5. Giupponi, C.; Ramanzin, M.; Sturaro, E.; Fuser, S. Climate and land use changes, biodiversity and agri-environmental measures in the Belluno province, Italy. Environ. Sci. Policy 2006, 9, 163-173. [CrossRef]

6. De Marchi, M.; Dal Zotto, R.; Cassandro, M.; Bittante, G. Milk coagulation ability of five dairy cattle breeds. J. Dairy Sci. 2007, 90, 3986-3992. [CrossRef] 
7. Battaglini, L.; Bovolenta, S.; Gusmeroli, F.; Salvador, S.; Sturaro, E. Environmental sustainability of alpine livestock farms. Ital. J. Anim. Sci. 2014, 13, 3155. [CrossRef]

8. Rinderzucht Austria. Breed Description of Pinzgauer and Alpine Grey. 2020. Available online: https: //zar.at/Rinderzucht-in-Oesterreich/Rinderrassen.html (accessed on 10 March 2020).

9. Visentin, G.; Penasa, M.; Gottardo, P.; Isaia, G.; Cassandro, M.; De Marchi, M. Milk coagulation properties of cattle breeds reared in alpine area. Poljoprivreda 2015, 21, 237-240. [CrossRef]

10. Marsoner, T.; Egarter Vigl, L.; Manck, F.; Jaritz, G.; Tappeiner, U.; Tasser, E. Indigenous livestock breeds as indicators for cultural ecosystem services: A spatial analysis within Alpine Space. Ecol. Indic. 2018, 94, 55-63. [CrossRef]

11. Province of Bolzano. Annual Report on Agriculture and Forestry of the Province of South Tyrol. 2020. Available online: http://www.provinz.bz.it/land-forstwirtschaft/landwirtschaft/agrar-forstbericht.asp (accessed on 7 April 2020).

12. South Tyrolean Dairy Association. Annual Report 2019. "Service rund um die Milch". 2020. Available online: https://www.suedtirolermilch.com/ueber-milch/sennereiverband-suedtirol (accessed on 16 June 2020).

13. Visentin, G.; Penasa, M.; Gottardo, P.; Cassandro, M.; De Marchi, M. Predictive ability of mid-infrared spectroscopy for major mineral composition and coagulation traits of bovine milk by using the uninformative variable selection algorithm. J. Dairy Sci. 2016, 99, 8137-8145. [CrossRef]

14. Benedet, A.; Manuelian, C.L.; Penasa, M.; Cassandro, M.; Righi, F.; Sternieri, M.; Galimberti, P.; Zambrini, A.V.; De Marchi, M. Factors associated with herd bulk milk composition and technological traits in the Italian dairy industry. J. Dairy Sci. 2018, 101, 934-943. [CrossRef] [PubMed]

15. Toffanin, V.; De Marchi, M.; Penasa, M.; Pretto, D.; Cassandro, M. Characterization of milk coagulation ability in bulk milk samples. Acta Agric. Slov. 2012, 3, 93-98.

16. Manuelian, C.L.; Penasa, M.; Visentin, G.; Cassandro, M.; De Marchi, M. Phenotypic analysis of milk coagulation properties and mineral content of Pinzgauer cattle breed. Arch. Anim. Breed. 2018, 61, 215-220. [CrossRef]

17. Niero, G.; Visentin, G.; Ton, S.; De Marchi, M.; Penasa, M.; Cassandro, M. Phenotypic characterisation of milk technological traits, protein fractions, and major mineral and fatty acid composition of Burlina cattle breed. Ital. J. Anim. Sci. 2016, 15, 576-583. [CrossRef]

18. Franzoi, M.; Niero, G.; Penasa, M.; Cassandro, M.; De Marchi, M. Technical note: Development and validation of a new method for the quantification of soluble and micellar calcium, magnesium, and potassium in milk. J. Dairy Sci. 2018, 101, 1883-1888. [CrossRef] [PubMed]

19. Holt, C. An equilibrium thermodynamic model of the sequestration of calcium phosphate by casein micelles and its application to the calculation of the partition of salts in milk. Eur. Biophys. J. 2004, 33, 421-434. [CrossRef] [PubMed]

20. Costa, A.; Visentin, G.; De Marchi, M.; Cassandro, M.; Penasa, M. Genetic relationships of lactose and freezing point with minerals and coagulation traits predicted from milk mid-infrared spectra in Holstein cows. J. Dairy Sci. 2019, 102, 7217-7225. [CrossRef]

21. Visentin, G.; Penasa, M.; Niero, G.; Cassandro, M.; De Marchi, M. Phenotypic characterisation of major mineral composition predicted by mid-infrared spectroscopy in cow milk. Ital. J. Anim. Sci. 2017, 17, 549-556. [CrossRef]

22. Franzoi, M.; Niero, G.; Visentin, G.; Penasa, M.; Cassandro, M.; De Marchi, M. Variation of detailed protein composition of cow milk predicted from a large database of mid-infrared spectra. Animals 2019, 9, 176. [CrossRef]

23. Costa, A.; Lopez-Villalobos, N.; Sneddon, N.W.; Shalloo, L.; Franzoi, M.; De Marchi, M.; Penasa, M. Invited review: Milk lactose-Current status and future challenges in dairy cattle. J. Dairy Sci. 2019, 102, 5883-5898. [CrossRef]

24. Breeders Association of Bolzano Province. "Tätigkeitsbericht 2019". 2020. Available online: https: //www.vstz.it/de/suedtiroler-tierzuchtvereinigung-service/downloads (accessed on 15 April 2020).

25. ZuchtData. Annual Report on Milk Performance. 2019. Available online: https://zar.at/Downloads/ Jahresberichte/ZuchtData-Jahresberichte.html (accessed on 2 April 2020).

26. Napoli, A.; Crespi, A.; Ragone, F.; Maugeri, M.; Pasquero, C. Variability of orographic enhancement of precipitation in the Alpine region. Sci. Rep. 2019, 9, 13352. [CrossRef] [PubMed]

27. Peratoner, G.; Kasal, A.; Plitzner, C. Stima del bilancio foraggero per l'Alto Adige. Quad. Sozooalp 2010, 6, 111-122. 